\title{
Analisis Sentimen Berbasis Ontologi di Level Kalimat untuk Mengukur Persepsi Produk
}

\author{
Agus Subhan Akbar ${ }^{\mathrm{a}, *}$, Eko Sediyono $^{\mathrm{b}}$, Oky Dwi Nurhayati $^{\mathrm{c}}$ \\ ${ }^{a}$ Mahasiswa Magister Sistem Informasi Universitas Diponegoro \\ ${ }^{\mathrm{b}}$ Magister Sistem Informasi Universitas Kristen Satya Wacana \\ ${ }^{\mathrm{c}}$ Jurusan Sistem Komputer, Fakultas Teknik, Universitas Diponegoro
}

Naskah Diterima : 15 Mei 2015; Diterima Publikasi : 17 Juli 2015

\begin{abstract}
The purpose of this research is to do sentiment analysis on tweets data retrieved using ontology framework and using naïve bayes classifier algorithm for classification process. This study is based on the habits of twitter users who frequently writes opinion, expression, or sentiment on a specific product, especially smartphones. These tweets can be used as a basis for sentiment analysis on a particular product. The method used in this study include the use of ontology framework for tweets retrieval that match the domain of the discussion and the use of naïve bayes classification algorithm for data classification. Classification process carried past the 3 pieces of layer classification to fine tune the final result of classification. Three layers of classification used include buzz/promo classification (classifying tweets into buzz and not-buzz tweets), subjectivity classification (classifying not-buzz tweets into subjective and objective tweets), and sentiment classification (classifying subjective tweets into positive, negative, or neutral tweets). The resulted software can classify tweets with high accuracy. This software was trained and tested with the composition of 25:75, 50:50, 75:25 from sample data and tested 10 times for each composition. Average accuracy of the system reached $84.16 \%, 86.15 \%$, and $87.54 \%$ for each composition. The result showed that by employing this system, product marketing stakeholders can determine the level of user sentiment expressed in the form of tweets. The method used in this study could be developed to improve the accuracy of classification systems.
\end{abstract}

Keywords: Sentence Level Sentiment Analysis; Ontology; Naïve Bayes, Classification

\begin{abstract}
Abstrak
Penelitian ini bertujuan untuk melakukan analisis sentimen pada data tweetsyang diambil dengan menggunakan kerangka ontologi dan menggunakan algoritma klasifikasi nä̈ve bayes untuk proses klasifikasinya. Penelitian ini didasarkan pada adanya kebiasaan pengguna twitter yang sering menulis pendapat, ekspresi, atau sentimen terkait produk tertentu, khususnya smartphone. Data tweets tersebut bisa digunakan sebagai basis analisis untuk mendapatkan sentimen atas produk tertentu. Metode yang digunakan dalam penelitian ini meliputi penggunaan kerangka ontologi untuk pengambilan data tweets yang sesuai dengan domain pembahasan dan penggunaan algoritma klasifikasi naïve bayes untuk proses pengklasifikasian data tweets sesuai dengan kategori yang ditentukan. Proses klasifikasi yang dilakukan melewati 3 buah lapisan klasifikasi untuk lebih menajamkan hasil akhir klasifikasi. Tiga lapisan klasifikasi yang digunakan meliputi klasifikasi buzz/promo(digunakan untuk memisahkan tweets promo dan bukan promo), klasifikasi subyektifitas (digunakan untuk memisahkan tweets bukan promo menjadi tweets subyektif dan obyektif), dan klasifikasi sentimen(digunakan untuk mendapatkan polaritastweets subyektif dalam bentuk sentimenpositif, negatif, atau netral). Hasil penelitian ini berupa perangkat lunak yang dapat mengklasifikasi tweetsdengan tingkat akurasi yang tinggi. Perangkat lunak tersebut dilatih dan diuji dengan komposisi 25:75, 50:50, dan 75:25dari data dan pengujian dilakukan sebanyak 10 kali untuk setiap komposisi. tingkat akurasi klasifikasi ratarata dari sistem yang dihasilkan mencapai $84.16 \%, 86.15 \%$, dan $87.54 \%$. Perangkat lunak ini dapat dikembangkan untuk membantu pihak-pihak terkait pemasaran produk smartphonesebagai alat bantu untuk mengetahui tingkat sentimen dari pengguna yang diekspresikan dalam bentuk tweets. Metode yang digunakan dalam penelitian ini masih bisa dikembangkan untuk meningkatkan tingkat akurasi klasifikasi sistem.
\end{abstract}

Kata kunci: Analisis Sentimen Level Kalimat; Ontologi; Nä̈ve Bayes, Klasifikasi

\section{Pendahuluan}

Informasi teks tertulis bisa dibagi menjadi dua kelompok besar, yaitu fakta dan opini (Liu, 2010). Fakta atau pengetahuan merupakan informasi obyektif terhadap suatu benda atau keadaan, sedangkan opini merupakan informasi subyektif yang berupa perasaan, penghargaan, ataupun penilaian terhadap benda atau suatu keadaan. Sesuai dengan

*) Penulis korespondensi: agussa@live.com 
kondisinya, opini ini bisa bersifat positif ataupun negatif.

Sifat positif atau negatif dari opini ini bisa digunakan untuk mengukur seberapa besar dukungan pembuat opini atas sebuah topik permasalahan. Bagi pembuat topik hal ini bisa digunakan untuk pengambilan langkah-langkah berikutnya terkait dengan topik permasalahan tersebut.

Persepsi produk merupakan gambaran pendapat, opini, atau perasaan konsumen terhadap produk tersebut. Persepsi ini bisa memiliki orientasi positif ataupun negatif. Bagi produsen, persepsi ini menjadi salah satu tolak ukur bagi keberhasilan produk yang dipasarkan tersebut. Sedangkan bagi konsumen, informasi persepsi ini berguna sebagai salah satu faktor untuk mengambil keputusan membeli produk tersebut. Produk yang populer akan mendapatkan opini ataupun komentar yang berjumlah banyak, bisa ratusan atau ribuan, sehingga diperlukan metode yang tepat untuk menghitung orientasi persepsi produk ini (Unnamalai, 2012).

Kemunculan Web 2.0 mengubah interaksi orang dengan internet yang semula sebagai pemakai pasif menjadi pemakai aktif. Salah satu aplikasi yang muncul dalam lingkup Web 2.0 adalah aplikasi twitter. Dengan aplikasi ini pengguna internet bisa mengekspresikan pendapatnya secara bebas baik dari sisi isi maupun waktu. Hal ini menjadikan twitter berisi data yang besar. Sampai dengan tahun 2013, pengguna aktif twitter mencapai 140 juta dengan jumlah tweets (teks yang dikirim) rata-rata mencapai 340 juta per-hari (Kontopoulos et al., 2013).

Tweets yang berjumlahratusan juta per-hari tersebut memiliki karakteristik yang khas yaitu adanya batasan panjang per-tweets yang berjumlah 140 karakter. Sehingga memunculkan tulisan-tulisan yang tidak mengikuti standar baku tata bahasa, adanya singkatan-singkatan, ataupun simbol-simbol tertentu yang digunakan oleh pengguna untuk mengekspresi-kan pendapatnya. Hal ini menimbulkan tantangan penelitian untuk mendapatkan metode-metode yang tepat untuk mendapatkan opini dan sentimen dari tweets tersebut (Zhang et al., 2011).

Analisis sentimen merupakan bidang riset yang terus berkembang sampai sekarang. Dalam bidang ini, penelitian difokuskan pada studi komputasi atas pendapat, sikap, dan emosi yang dituliskan dalam bentuk teks (Medhat et al., 2014). Sasaran analisis sentimen ini adalah untuk menemukan opini/pendapat yang ada dalam tulisan teks, mendapatkan sentimen yang ada dalam opini yang ditemukan, dan pada ujungnya mendapatkan polaritas/klasifikasi atas sentimen tersebut apakah positif/mendukung atau negatif/tidak mendukung.

Analisis sentimen ini terbagi menjadi tiga jenis, yang terdiri atas: document level sentiment analysis, sentence level sentiment analysis, dan aspect-level sentiment analysis (Medhat et al., 2014). Document level sentiment analysis merupakan bidang analisis sentimen dengan masukan dokumen pembahasan tentang satu tema yang dianggap sebagai satu unit masukan. Sentence level sentiment analysis disisi lain merupakan bidang analisis sentimen dengan masukan berupa satu kalimat sabagi satu unit masukan. Level yang lebih detail dari analisis sentimen ini adalah aspect-level sentiment analysis dengan melakukan klasifikasi sentimen atas aspek tertentu dari entitas yang dibahas, seperti sentimen atas spesifikasi dari produk yang lebih detail dari sekedar sentimen atas produk.

Algoritma yang digunakan untuk melakukan klasifikasi sentimen terbagi menjadi dua bagian besar yaitu algoritma yang berbasis kamus (Taboada et al., 2011; Maks dan Vossen, 2012; Unnamalai, 2012; Kontopoulos et al., 2013) dan berbasis pembelajaran (Ghiassi et al., 2013; He dan Zhou, 2011; Zhou et al., 2014). Penggunaan algoritma klasifikasi sentimen berbasis kamus dengan cara memecah kalimat yang akan dianalisis menjadi sejumlah kata pembentuknya. Kata-kata yang mengandung sentimen dipilih, diproses dengan menggunakan kamus sentimen online seperti SentiWordNet, untuk mendapatkan nilai orientasi dari kata-kata tersebut. Berdasarkan nilai orientasi dari kata-kata tersebut, orientasi sentimen atas kalimat itu bisa ditentukan apakah dominan positif, negatif atau netral.

Algoritma klasifikasi sentimen berbasis pembelajaran disisi lain menggunakan proses pembelajaran terhadap data trainning yang sudah disediakan. Algoritma pembelajaran yang dipakai diantaranya Nä̈ve Bayes(NB) (He dan Zhou, 2011), Support Vector Machine (SVM) (Ghiassi et al., 2013; $\mathrm{He}$ dan Zhou, 2011), Maximum Entropy(ME) (He dan Zhou, 2011), atau Fuzzy-NN (Zhou et al., 2014). Data pelatihan untuk keperluan pembelajaran disiapkan dan ditandai apakah positif, negatif, atau netral. Berdasarkan hasil pelatihan, masukan kalimat baru yang akan dianalisis dimasukkan ke sistem yang sudah dilatih dan sistem menghasilkan orientasi atas kalimat tersebut apakah positif, negatif, atau netral. Algoritma klasifikasi Nä̈ve Bayes (NB) dibuktikan menghasil-kan klasifikasi yang lebih baik dibandingkan dengan algoritma Support Vector Machine (SVM), dan Maximum Entropy (ME) melalui 10 kali percobaan (He dan Zhou, 2011). Nä̈ve Bayes juga digunakan dalam deteksi intrusi untuk mengklasifikasi data menjadi lima kelompok kelas yaitu: Normal, Probe (gathering information), $D o S$ (denial of service), U2R (user to root), $R 2 L$ (remote to local) (Mukherje dan Sharma, 2012).

Pendekatan terbaru dalam bidang analisis sentimen ini adalah penggunaan teknologi semantik web untuk lebih meningkatkan hasil analisis yang didapatkan dari penggunaan pemrosesan bahasa natural dan analisis sentimen (Peñalver-Martinez et al., 2014). Analisis dalam penelitian tersebut dilakukan pada dokumen seperti pada ulasan lengkap 
tentang produk dengan kemungkinan aspek-aspek detail dari entitas dengan nilai sentimen yang berbeda untuk setiap aspeknya. Teknik semantik web yang digunakan adalah pemilihan fitur untuk analisis sentimen dengan menggunakan kerangka ontologi, yang pada fase berikutnya menghasilkan data vektor yang digunakan sebagai masukan untuk analisis sentimen.

Kerangka ontologi merupakan pemaparan konsep pengetahuan beserta hubungan antar konsep tersebut sehingga tercipta keterkaitan antar masing-masing konsep. kerangka ini bisa digambarkan dalam sebuah pohon pengetahuan. Tujuan penggambaran ini supaya bisa dimengerti oleh manusia maupun mesin / komputer. Penggunaan kerangka ontologi dalam penelitian ini untuk mempertajam atau membatasi hasil pencarian data tweets yang sesuai dengan domain yang akan diteliti.

Penyusunan hasil klasifikasi sentimen dalam rentang waktu tertentu akan lebih bisa menggambarkan perkembangan persepsi orang atas topik tertentu. Sehingga pihak yang berkepentingan bisa mengambil langkah-langkah tertentu atas hasil perkembangan persepsi tersebut. Visualisasi grafik batang ataupun berbentuk lingkaran akan lebih memudahkan bagi pihak yang berkepentingan untuk mendapatkan pengertian atas hasil klasifikasi tersebut (Chen et al., 2014).

Penelitian ini akan menggunakan kerangka ontologi untuk memetakan data tweets. Data tweets yang didapat, diproses dengan stanford pos tagger untuk mendapatkan struktur detail kalimat yang digunakan untuk memisahkan tweets subyektif dan obyektif. Tweets subyektif (berisi pendapat) diklasifikasi dengan algortima nä̈ve bayes untuk mendapatkan orientasi dari tweets tersebut. Hasil klasifikasi akan ditampilkan dalam bentuk angka ataupun grafik sehingga memudahkan bagi pengguna untuk mendapatkan pengertian atas hasil klasifikasi sentimen tersebut.

\section{Kerangka Teori}

\subsection{Analisis Sentimen}

Analisis sentimen merupakan studi komputasi linguistik tentang pendapat, ekspresi, dan perasaan orang terhadap entitas, individu, topik, atau obyek lain yang ditulisan dalam bentuk teks (Liu, 2011). Pendapat ini penting, karena seringkali individu ataupun perusahaan memutuskan sesuatu terlebih dahulu memandang pendapat dari pihak lain.

Opini/pendapat ini bisa direpresentasikan dengan lima variabel yang bisa ditulis dalam persamaan (1) berikut ini:

$$
\text { Opinion }=\left(e_{i}, a_{i, j}, o o_{i, j, k, l}, h_{k}, t_{l}\right)
$$

Dimana $e_{i}$ adalah entitas atau topik yang dibicarakan, $a_{i, j}$ merupakan aspek dari $e_{i}$. Sedangkan $\mathbf{o o}_{i, j, k, l}$ merupakan orientasi dari $\mathrm{a}_{\mathrm{i}, \mathrm{j}}$ terhadap $\mathrm{e}_{\mathrm{i}}$. Orientasi oo ini bisa bernilai positif, negatif, ataupun netral. Variabel $h_{k}$ merupakan subyek/orang yang menuliskan opini, dan $\mathrm{t}_{1}$ merupakan waktu saat $\mathrm{h}_{\mathrm{k}}$ menulis opini tersebut.

\subsection{Model Ontologi}

Ontologi merupakan suatu cara untuk memaparkan pengetahuan atas sebuah konsep dan hubungannya dengan konsep lain sehingga tercipta hubungan keterkaitan yang bisa direpresentasikan dalam bentuk pohon pengetahuan. Representasi ini ditujukan untuk bisa dimengerti baik oleh mesin maupun pengguna.

Komponen dalam ontologi terdiri atas: obyek, klas, atribut, dan relasi yang menghubungkan antar obyek. Untuk domain smartphone sebagai contoh, konsep atau istilah yang ada didalamnya meliputi merk, sistem operasi, dan spesifikasi teknis dari perangkat. Spesifikasi teknis dari perangkat ini bisa didetailkan meliputi prosesor yang ada didalamnya, kapasitas memori, fasilitas koneksi, baterai, kamera, dan spesifikasi teknis lainnya. Salah satu pemodelan ontologi dengan menggunakan OntoGen (http://ontogen.ijs.si) untuk smartphone seperti yang terlihat padagambar1 berikut ini:

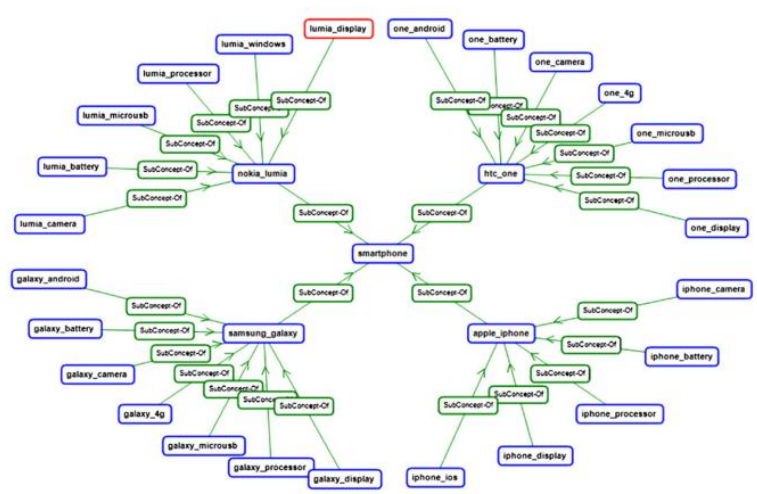

Gambar 1.Visualisasi ontologi domain smartphone dengan OntoGen (Kontopoulos et al., 2013)

\subsection{Stanford POS Tagger}

Informasi teks tersusun dengan struktur tata bahasa yang sesuai dengan bahasa yang digunakan. Struktur kata dalam tata bahasa meliputi adanya kata benda, kata kerja, kata sifat, dan kata keterangan beserta variasi yang lain. Salah satu yang membedakan bahwa informasi teks tersebut mengandung opini/pendapat dengan yang bersifat obyektif adalah penggunaan kata sifat dan atau kata keterangan. Untuk itu perlu adanya sebuah metode untuk memproses kalimat itu dan membaginya menjadi kata per kata sesuai kelompoknya.

POS Tagger (Part-of-speech Tagger) merupakan perangkat lunak pemrosesan bahasa) natural yang digunakan untuk mengurai kata-kata penyusun kalimat dan mengelompokkannya ke dalam kelas kata masing-masing (Toutanova et al., 2003). Salah 
satu perangkat lunak POS Tagger ini adalah Stanford Pos Tagger (http://nlp.stanford.edu/software/tagger.shtml ). Kelas kata yang didukung oleh perangkat lunak ini seperti dalam tabel 1 berikut:

Tabel1. Kelas kata dalam proyek Penn Treebank (https://www.ling.upenn.edu/courses/Fall_2003/ling0 01/penn_treebank_pos.html)

\begin{tabular}{ll}
\hline Tag & Deskripsi \\
\hline CC & Coordinating conjunction \\
CD & Cardinal number \\
DT & Determiner \\
EX & Existential there \\
FW & Foreign word \\
IN & Preposition or subordinating conjunction \\
JJ & Adjective \\
JJR & Adjective, comparative \\
JJS & Adjective, superlative \\
LS & List item marker \\
MD & Modal \\
NN & Noun, singular or mass \\
NNS & Noun, plural \\
NNP & Proper noun, singular \\
NNPS & Proper noun, plural \\
PDT & Predeterminer \\
POS & Possessive ending \\
PRP & Personal pronoun \\
PRP\$ & Possessive pronoun \\
RB & Adverb \\
RBR & Adverb, comparative \\
RBS & Adverb, superlative \\
RP & Particle \\
VB & Verb, base form \\
SYM & Symbol \\
TO & to \\
UH & Interjection \\
VBD & Verb, past tense \\
VBG & Verb, gerund or present participle \\
VBN & Verb, past participle \\
VBP & Verb, non-3rd person singular present \\
VBZ & Verb, $3 r d$ person singular present \\
WDT & Wh-determiner \\
WP & Wh-pronoun \\
WP\$ & Possessive wh-pronoun \\
WRB & Wh-adverb \\
\hline &
\end{tabular}

\subsection{IPostagger}

IPostagger merupakan POS Tagger yang dikembangkan untuk Bahasa Indonesia berbasis Hidden Markov Model (HMM) (Wicaksono dan Purwarianti, 2010). IPostagger menggunakan metode tambahan dengan menyusun pohon afiks yang meliputi awalan dan akhiran disertai dengan penggunaan kosa kata yang diambil dari Kamus Besar Bahasa Indonesia (KBBI - Kateglo) untuk membatasi hasil dari pemrosesan pohon afiks.

Kelas kata (Tag set) yang digunakan dalam IPostagger ini seperti dalam tabel 2 berikut ini:
Tabel 2. Kelas kata dalam IPostagger (Wicaksono dan Purwarianti, 2010)

\begin{tabular}{|c|c|c|}
\hline Tag & Keterangan & Contoh \\
\hline OP & Open Parenthesis & $(\{[$ \\
\hline $\mathrm{CP}$ & Close Parenthesis & )$\}]$ \\
\hline GM & Slash & l \\
\hline ; & Semicolon & ; \\
\hline : & Colon & : \\
\hline “ & Quotation & ، ، \\
\hline . & Sentence Terminator & !? \\
\hline , & Comma & , \\
\hline - & Dash & - \\
\hline$\ldots$ & Ellipsis & $\ldots$ \\
\hline $\mathrm{JJ}$ & Adjective & Kaya, Manis \\
\hline $\mathrm{RB}$ & Adverb & Sementara, Nanti \\
\hline $\mathrm{NN}$ & Common Noun & Mobil \\
\hline NNP & Proper Noun & Bekasi, Indonesia \\
\hline NNG & Genitive Noun & Bukunya \\
\hline VBI & Intransitive Verb & Pergi \\
\hline VBT & Transitive Verb & Membeli \\
\hline IN & Proposition & Di, Ke, Dari \\
\hline MD & Modal & Bisa \\
\hline $\mathrm{CC}$ & Coor-Conjunction & Dan, Atau, Tetapi \\
\hline $\mathrm{SC}$ & Subor-Conjunction & Jika, Ketika \\
\hline DT & Determiner & Para, Ini, Itu \\
\hline $\mathrm{UH}$ & Interjection & Wah, Aduh, Oi \\
\hline $\mathrm{CDO}$ & Ordinal Numerals & Pertama, Kedua \\
\hline $\mathrm{CDC}$ & Collective Numerals & Bertiga \\
\hline CDP & Primary Numerals & Satu, Dua \\
\hline CDI & Irregular Numerals & Beberapa \\
\hline PRP & Personal Pronouns & Saya, Kamu \\
\hline WP & WH-Pronouns & Apa, Siapa \\
\hline PRN & Number Pronouns & Kedua-duanya \\
\hline PRL & Locative Pronouns & Sini, Situ, Sana \\
\hline NEG & Negation & Buka, Tidak \\
\hline SYM & Symbols & $@ \# \$ \% \wedge \&$ \\
\hline $\mathrm{RP}$ & Particles & Pun, Kah \\
\hline FW & Foreign Words & Foreign, Word \\
\hline
\end{tabular}

\subsection{Subjectivity/Opinion Extraction}

Subjectivity Extraction merupakan proses untuk memilah apakah tweets berisi pendapat ataukah tidak. Jadi proses ini lebih untuk memisahkan tweets yang berisi pendapat, expresi, atau opini dengan tweets yang hanya berisi berita (Liu, 2010).

Salah satu cara untuk memilah apakah tweets tersebut berisi opini adalah dengan menggunakan POS tagger dan melakukan pengecekan jika terdapat kata sifat atau kata keterangan maka tweets tersebut memiliki kemungkinan besar adalah sebuah opini.

\subsection{Sentence Level Sentiment Classification (Nä̈ve Bayes Classifier)}

Analisis sentimen ditingkat kalimat merupakan subbidang penelitian dari analisis atau klasifikasi sentimen. Level kalimat berarti yang dianalisis adalah satu kalimat dengan memperhatikan kata-kata penyusun kalimat tersebut. 
Nä̈ve Bayes Classifier merupakan algoritma klasifikasi text sederhana yang dikembangakan berdasarkan teorema Bayes dengan asumsi atas variabel-variabel yang terlibat saling bebas satu dengan yang lainnya. Sehingga pada saat digunakan dalam analisis kalimat, setiap kata dalam kalimat tersebut dianggap saling bebas terhadap kata yang lain. Teknik klasifikasi ini sering digunakan untuk mendeteksi email sampah (spam email), klasifikasi teks, dan pengelompokan dokumen.

Formulasi yang digunakan dalam algoritma klasifikasi ini ditujukan untuk mendapatkan nilai maksimal dari "maximum a posteriori" (MAP) sesuai dengan persamaan(2) dan (3) berikut ini (Zhang, 2004; Manning et al., 2008):

$C_{\text {map }}=$

$\arg \max _{c \in C}(P(c \mid d))=$

$\arg \max _{c \in C}\left(P(c) \prod_{1 \leq k \leq n_{d}} P\left(t_{k} \mid c\right)\right)$

$P(t \mid c)=\frac{T_{c t}+1}{\sum_{t^{\prime} \in V}\left(T_{c t^{\prime}}+1\right)}=\frac{T_{c t}+1}{\sum_{t^{\prime} \in V}\left(T_{c t^{\prime}}\right)+B^{\prime}}$

Dimana $t_{k}$ merupakan token/kata yang ada dalam dokumen/kalimat, $\mathrm{C}$ merupakan klas pengelompokan (positif, negatif, netral), $\mathrm{P}(\mathrm{c} \mid \mathrm{d})$ merupakan probabilitas bersyarat klas $\mathrm{c}$ dari dokumen/kalimat $\mathrm{d}$, $\mathrm{P}(\mathrm{c})$ merupakan probabilitas awal/sebelumnya dari klas $\mathrm{c}, \mathrm{P}\left(\mathrm{t}_{\mathrm{k}} \mid \mathrm{c}\right)$ merupakan probabilitas bersyarat dari token $t_{k}$ dalam kelas $c$, dan $B^{\prime}$ merepresentasikan jumlah term/token yang ada dalam pustaka yang digunakan.

Perhitungan performa merupakan formulasi untuk perhitungan performa yang digunakan. Formula yang digunakan meliputi precision, recall, accuracy, dan F-Measure (Haddi et al., 2013). Masing-masing bisa dihitung dari parameter yang berasal dari keberhasilan sistem dalam mengenali fitur yang ada yang meliputi True Positif (TP), False Positif (FP), True Negatif(TN), dan False Negatif(FN). Parameterparameter ini bisa lebih jelas digambarkan dalam gambar 2 berikut ini:

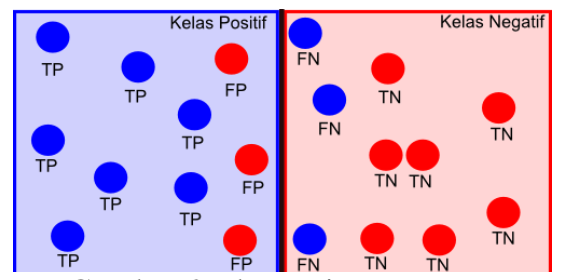

Gambar 2. Ilustrasi Parameter

Berdasarkan gambar 2 di atas, TP merupakan item positif yang berhasil diklasifikasi sebagai kelas positif, FP merupakan item negatif yang diklasifikasi sebagai kelas positif, TN merupakan item negatif yang diklasifikasi dalam kelas negatif, sedangkan FN merupakan item positif yang diklasifikasi sebagai kelas negatif.
Perhitungan performa untuk klasifikasi biner (2 kelas/kategori) yang diperlihatkan pada gambar 2 di atas bisa dinyatakan seperti pada persamaan (4), (5), (6), dan (7) berikut ini:

$$
\begin{aligned}
& \text { precision }=\frac{T P}{T P+F P} \\
& \text { recall }=\frac{T P}{T P+F N} \\
& \text { accuracy }=\frac{T P+T N}{T P+F P+T N+F N} \\
& F-\text { Measure }=\frac{2 * \text { precission } * \text { recall }}{\text { precission +recall }}
\end{aligned}
$$

Berdasarkan persamaan (4), precision merupakan perbandingan atas jumlah klasifikasi yang benar dibandingkan dengan total item yang berhasil diklasifikasi di kelas positif. Recall, yang dinyatakan dalam persamaan (5), merupakan perbandingan atas jumlah klasifikasi yang benar dengan jumlah item yang seharusnya berada dalam kelas tersebut. Accuracy, yang dituliskan dalam persamaan (6), merupakan perbandingan jumlah ketepatan klasifikasi atas semua item yang diklasifikasi. Nilai accuracy ini digunakan untuk perhitungan ketepatan klasifikasi untuk seluruh kelas yang ada dalam klasifikasi.

F-Measure yang dinyatakan dalam persamaan (7) merupakan perhitungan rata-rata antara precision dan recall. F-Measure merupakan salah satu metode pengambilan rata-rata yang juga disebut dengan harmonic mean. Perhitungan ini merupakan nilai rata-rata dari variabel dengan rentang nilai yang sama $(0<=\mathrm{x}<=1)$ tetapi dari cara penilaian yang berbeda (precision dan recall).

Perhitungan accuracy yang digunakan untuk mencari tingkat keakuratan model untuk klasifikasi lebih dari dua kelas (n-class) bisa dinyatakan dalam persamaan (8) berikut ini:

$$
\text { accuracy }=\frac{\sum_{i=1}^{n} T P_{i}}{\sum_{i=1}^{n}\left(T P_{i}+F P_{i}\right)}
$$

\subsection{Siklus Pengembangan Perangkat Lunak}

Salah satu metodologi pengembangan perangkat lunak yang ada adalah metodologi Extreme Programming $(X P)$. Siklus pengembangan perangkat lunak yang mengadopsi metodologi ini melewati 5 fase yang terdiri atas: Eksplorasi, Perencanaan, dan iterasi tahapan release, produksi, perawatan, dan penyelesaian. Tahapan-tahapan dalam metodologi $X P$ ini bisa digambarkan secara lebih detail dalam gambar 3 berikut ini (Abrahamsson et al., 2002): 


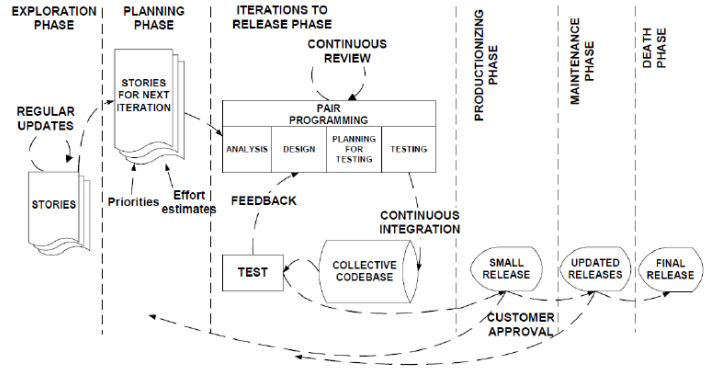

Gambar 3.Siklus tahapan dalam metodologi XP (Abrahamsson et al., 2002)

Fase eksplorasi merupakan tahapan bagi pengguna dalam proses pengembangan perangkat lunak untuk merumuskan dan menuliskan kebutuhankebutuhan yang paling mendasar dari sistem yang disebut dengan User Story. Sedangkan dari sisi pengembang akan mencari sejumlah alternatif arsitektur sistem yang bisa digunakan. Untuk penelitian ini, fase eksplorasi merupakan fase bagi peneliti untuk mempelajari tentang kebutuhan sistem dan mencoba sejumlah alternatif perangkat yang dibutuhkan dalam pengembangan sistem.

Fase perencanaan yang merupakan kelanjutan dari fase sebelumnya digunakan untuk memilah dari sejumlah kebutuhan sistem yang ada. Kebutuhan yang paling utama dan paling menggambarkan sistem dipilih untuk kemudian dimulai pembuatannya. Penjadwalan lebih detail untuk penyelesaian kebutuhan-kebutuhan tersebut juga dibuat pada tahapan ini.

Fase berikutnya adalah iterasi pengembangan sistem. Dalam fase ini ada empat tahapan yang akan diulang beberapa kali untuk menyelesaikan pengembangan sistem. Iterasi langkah yang ada meliputi analisis, desain, perencanaan uji coba, dan uji coba. Jika ada yang kurang dalam satu siklus maka akan ada iterasi berikutnya untuk menyelesaikan saran-saran pengembangan yang ada.

Fase berikutnya adalah tahapan melakukan rilis pertama dari perangkat lunak yang telah dihasilkan. Selama rilis tersebut tentu akan ada kritik dan saran untuk memperbaiki software. Pengembangan ini bisa saja diulang beberapa kali sesuai dengan kritik dan saran yang ada. Tahapan ini sudah masuk ke dalam fase perawatan.

Fase terakhir adalah rilis final. Rilis final dilakukan jika kebutuhan sistem sudah dipenuhi dan sudah berfungsi sesuai dengan kebutuhan. Rilis Final ini juga bisa merupakan akhir dari fase pengembangan perangkat lunak untuk versi tersebut. Fase pengembangan berikutnya bisa dilakukan dengan memulai dari awal.

\section{Metodologi}

\subsection{Bahan Penelitian}

Penelitian analisis sentimen berbasis ontologi di level kalimat ini akan membutuhkan sejumlah bahan dan alat penelitian. Bahan penelitian yang dibutuhkan berupa sejumlah data yang digunakan untuk menguji kerangka sistem yang dibangun. Sedangkan alat penelitian meliputi perangkat yang dibutuhkan selama penelitian meliputi perangkat lunak dan perangkat keras.

Bahan-bahan yang akan digunakan dalam penelitian ini adalah data yang diambil dari twitter tentang produk yang akan digunakan sebagai bahan untuk masukan sistem klasifikasi yang dikembangkan. Karakteristik data twitter atau biasa disebut dengan tweets ini meliputi:

a. Tweets memiliki panjang maksimal 140 karakter.

b. Tweets kadang ditambahi dengan hashtag yang biasanya untuk lebih fokus pada pembahasan topik tertentu, misalnya: \#smartphone

c. Tweets bisa berupa perulangan atau mendukung atas tweet yang lain, atau istilahnya retweet, biasanya dideteksi dengan adanya simbol RT.Retweet ini ada 2 jenis yaitu Original Retweet dan Retweet With Quote.

d. Dalam Tweets kadang bisa berisi link atau url.

e. Saat Tweets dikirimkan, Informasi waktu yang meliputi jam, tanggal, bulan, dan tahun ikut dikirimkan secara otomatis.

Produk yang akan digunakan dalam penelitian ini terdiri atas data tweets yang terkait dengan produk smartphone. Data tweets terkait smartphone ini akan diambil dari twitter dengan menggunakan Twitter API(API yang disediakan oleh Twitter) dengan memanfaatkan pustaka Twitter4j.

\subsection{Alat Penelitian}

Alat-alat yang digunakan dalam penelitian ini meliputi perangkat keras, perangkat lunak sistem, dan perangkat lunak bantu lainnya. Berikut detail spesifikasi peralatan yang digunakan:

1. Perangkat Keras komputer dengan spesifikasi prosesor 2.0 Ghz atau yang lebih tinggi, Memory $4 \mathrm{~Gb}$ atau yang lebih tinggi, Harddisk $120 \mathrm{~Gb}$ atau yang lebih tinggi, Kartu Jaringan untuk koneksi internet, dan perangkat pelengkap lainnya.

2. Perangkat Lunak Sistem yang digunakan meliputi:

a. Sistem Operasi Windows 7 atau yang lebih tinggi

b. Java Development Kit Versi 6 atau lebih tinggi

c. IDE Pengembangan NetBeans 8

d. Twitter API SDK, Twitter4J 4.0.2

e. MySQL Database Server

f. Apache Http Server

g. Komponen Pemrograman Grafik JFreeChart 1.0.19.

\subsection{Prosedur Penelitian}

Penelitian ini akan diawali dengan studi pustaka, identifikasi permasalahan, penyusunan kerangka sistem berbasiskan metode yang dipilih, 
pengumpulan data, perancangan sistem, dan ujicoba sistem. Pengembangan perangkat lunak dalam penelitian ini mengikuti konsep Extreme Programming (XP).

\subsubsection{Identifikasi Permasalahan}

Tweets yang dikirim ke twitter berjumlah sangat besar setiap harinya. Rata-rata per-hari mencapai 340 juta tweets (Kontopoulos et al., 2013). Isi dari tweets tersebut bervariasi dari semua bidang. Dari yang berisi tentang opini sebuah produk, opini keseharian pengguna, debat antar pengguna, informasi teknologi terbaru, dan promo-promo (marketing buzz) yang demikian besarnya. Data tweets yang berjumlah besar ini bisa dimanfaatkan untuk mendapatkan penilaian atau sentimen dari pengguna terhadap produk tertentu seperti smartphone.

Keterbatasan panjang karakter dalam tweets yang hanya berjumlah maksimal 140 karakter terkadang menjadikan para pengguna menuliskan tweets mereka dengan kata-kata yang disingkat, menggunakan bentuk lain dari kata tersebut, ataupun dengan memberikan link / url ke halaman web lain.

Beberapa perusahaan periklanan di internet menggunakan twitter untuk mendistribusikan konten iklan yang dipesan oleh pemasang iklan dan menerima pendaftaran dari para pengguna twitter untuk ikut terlibut mendistribusikan konten iklan tersebut dengan imbalan finansial. Konten-konten ini sering disebut dengan marketing buzz atau tweets promo. Untuk klasifikasi sentimen, tweets seperti ini dikecualikan.

Contoh-contoh tweets terkait seperti berikut ini:

1. The iPhone 6 battery life is amazing

2. Useful informations for iPhone 6 users. http://t.co/M5PjdhUU56

3. TODAY DEALS \#933 > http://t.co/BNpfSMEm8FMonoprice 2200mAh External Backup Battery Charger for iPhone 3 3GS 4... http://t.co/hAjLLUOh2x

4. Phones Offers >> http://t.co/LPK9kSAf35 \#034 New Original Battery EB-BG900BBEGWW For Samsung Galaxy S5 i9600 G9... http://t.co/e3k9vb2ZIa

5. \#BestPrice - Genuine Battery For Samsung Galaxy Not... http://t.co/fZnReykesh \#Deals_UK| https://t.co/jj6D7nVuDj http://t.co/HhIgXAePlZ

Dari contoh-contoh tersebut di atas, menjadi sebuah tantangan untuk membangun sebuah sistem klasifikasi sentimen berbasis ontologi atas opini yang disampaikan oleh pengguna twitter terkait tentang produk smartphone dalam penelitian ini. Tweets yang terkait dengan smartphone tetapi berisi marketing buzz juga perlu dikecualikan dari sistem.

\subsubsection{Karakteristik Tweets}

Tweets, pada awalnya, merupakan bentuk ekspresi atau pendapat yang dikirim oleh pengguna ke media sosial twitter. Isi tweets terkait dengan bidang apa saja yang menjadi perhatian pengguna. Akan tetapi perkembangan terkini, tweets juga digunakan sebagai media penyebar informasi, media iklan (marketing buzz), selain tetap sebagai media ekspresi oleh pengguna.

Terkait dengan klasifikasi opini / sentimen dalam penelitian ini, Tweets yang digunakan sebagai dasar bisa terdiri atas:

1. Tweets asli, yang merupakan asli tulisan dari pengguna, dan

2. Retweets yang merupakan dukungan dari pengguna yang lain atas tweets asli dengan membagikan tweets ini ke pengikutnya dan juga bisa memberikan tambahan komentar terhadap tweets tersebut sebelum dibagi. Retweets ini sesuai dengan dokumentasi dari twitter.com bisa berupa original retweets dan retweets with quote. Original retweets merupakan dukungan terhadap tweets asli tanpa menambahi komentar lebih lanjut, sedangkan retweets with quote bisa berisi tambahan komentar atas tweets asli.

Penelitian ini menggunakan pustaka Twitter4J yang dapat membedakan masing-masing tweets tersebut. Salah satu fungsi dalam pustaka Twitter4J adalah fungsi isRetweet(). Fungsi ini akan mengembalikan nilai false untuk tweets asli yang berhasil di download. Untuk original retweets, fungsi ini akan mengembalikan nilai true. Sedangkan untuk retweets with quote, fungsi ini akan mengembalikan nilai false.

Dengan demikian, untuk original retweets akan dihitung sebagai dukungan terhadap tweets asli. Jika tweets asli berorientasi positif, maka original retweets dihitung sama dengan tweets aslinya, begitu juga sebaliknya. Di penelitian yang lain original retweets ini tidak dimasukkan dalam analisis (Zhang et al., 2011). Sedangkan untuk tweets asli dan retweets with quote tetap akan dimasukkan ke dalam model klasifikasi sentimen.

\subsubsection{Penggunaan Ontologi}

Desain ontologi sebagi basis pengetahuan memegang peranan penting untuk mempertajam dan mempersempit hasil pencarian yang dilakukan dengan menggunakan pustaka Twitter4J. Sehingga hanya tweets dari domain yang ditentukan saja yang diberikan oleh twitter.com pada saat proses pengambilan / downloadtweets.

Desain ontologi yang digunakan dalam penelitian ini dikembangkan dari desain ontologi yang ada di gambar 1 dengan penambahan obyek. Domain yang digunakan adalah smartphone dengan obyek meliputi iphone, galaxy, htc, lumia, dan xiaomi. Untuk masing-masing obyek tersebut ditentukan sejumlah sub konsep/atribut yang meliputi battery, camera, microusb, processor, dan display. Penyusunan kerangka ontologi dalam penelitian ini dibuat dengan menggunakan perangkat lunak ontogen versi 2.0.0. 
Hasil rancangan kerangka ontologi yang dibuat ditampilkan dalam gambar 4 berikut ini:

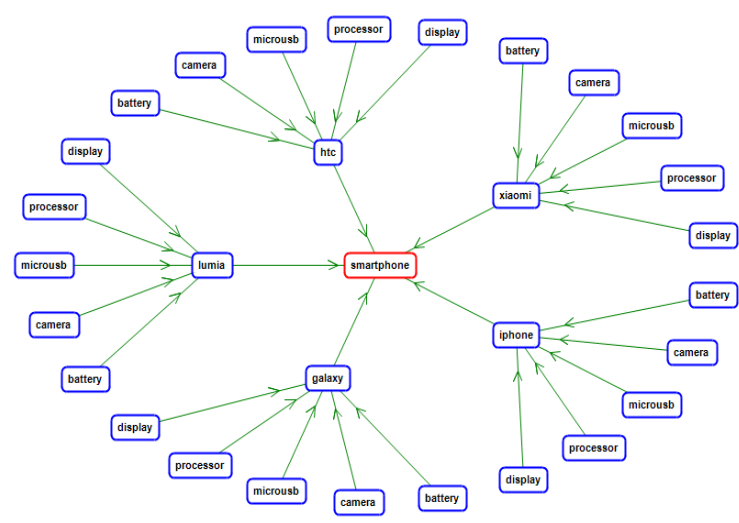

Gambar 4. Visualisasi ontologi domain smartphone untuk penelitian ini dengan Ontogen 2.0.0

Berdasarkan ontologi yang dibangun di atas, dilakukan pencarian tweets di twitter.com dengan menggunakan twitter 4 . Untuk setiap kombinasi obyek dan atribut yang ada disusun sebagai keyword pencarian. Sebagai contoh untuk obyek iphone dan atribut battery maka keyword yang digunakan adalah "iphone battery" (dengan tanpa tanda petik) (Kontopoulos et al., 2013).

\subsubsection{Perhitungan Algoritma Nä̈ve Bayes}

Algoritma klasifikasi nä̈ve bayes digunakan untuk melakukan klasifikasi terhadap data tweets. Sebelum digunakan untuk melakukan klasifikasi, algoritma ini perlu dilatih terlebih dahulu dengan sejumlah data latih. Contoh pelatihan dan penggunaan algoritma ini seperti pada penjelasan berikut ini. Contoh data tweets beserta anotasi manualnya seperti pada tabel 3 berikut ini:

Tabel 3. Contoh data tweets dan anotasinya

\begin{tabular}{ll}
\hline Tweets & klas \\
\hline The iPhone 6 battery life is amazing & positif \\
This iPhone battery is amazing & positif \\
The Galaxy s5 battery life is amazing & positif \\
The camera on the iPhone 6 is literally & positif \\
amazing & \\
iPhone battery is so shit & negatif \\
Galaxy s5 camera is shit & negatif \\
Iphone 4s camera quality shit & negatif \\
iPhone battery life is ridiculously shit & negatif \\
\hline
\end{tabular}

Berdasarkan data di atas, prior probability, $\mathrm{P}(\mathrm{C})$, untuk masing-masing kelas adalah $\mathrm{P}($ positif $)=4 / 8=$ 0.5 dan $P($ negatif $)=4 / 8=0.5$. Data statistik yang didapat dari data di atas seperti tertuang dalam tabel 4 berikut ini:
Tabel 4. Data statistik dari contoh data

\begin{tabular}{lc}
\hline Data & Jumlah \\
\hline Jumlah kata & 49 \\
Jumlah kata tanpa duplikat & 18 \\
Jumlah kata dalam kelas positif & 28 \\
Jumlah kata dalam kelas negatif & 21 \\
Jumlah kata unik dalam kelas positif & 10 \\
Jumlah kata unik dalam kelas negatif & 17 \\
\hline
\end{tabular}

Perhitungan peluang bersyarat untuk masingmasing kata dihitung dengan menggunakan persamaan (3). Hasil perhitungan peluang bersyarat ini ditampilkan pada tabel 5 berikut ini:

Tabel 5. Perhitungan peluang bersyarat

\begin{tabular}{llcc}
\hline No & Kata $(\mathrm{x})$ & $\mathrm{P}(\mathrm{x} \mid \mathrm{positif})$ & $\mathrm{P}(\mathrm{x} \mid$ negatif $)$ \\
\hline 1 & $4 s$ & 0.0263 & 0.0526 \\
2 & 6 & 0.0789 & 0.0263 \\
3 & amazing & 0.1316 & 0.0263 \\
4 & battery & 0.1053 & 0.0789 \\
5 & camera & 0.0526 & 0.0789 \\
6 & Galaxy & 0.0526 & 0.0526 \\
7 & iPhone & 0.1053 & 0.1053 \\
8 & is & 0.1316 & 0.1053 \\
9 & life & 0.0789 & 0.0526 \\
10 & literally & 0.0526 & 0.0263 \\
11 & on & 0.0526 & 0.0263 \\
12 & quality & 0.0263 & 0.0526 \\
13 & ridiculously & 0.0263 & 0.0526 \\
14 & s5 & 0.0526 & 0.0526 \\
15 & shit & 0.0263 & 0.1316 \\
16 & so & 0.0263 & 0.0526 \\
17 & The & 0.1316 & 0.0263 \\
18 & This & 0.0526 & 0.0263 \\
\hline
\end{tabular}

Berdasarkan data prior probability masingmasing kelas dan peluang bersyarat masing-masing kata, maka perhitungan klasifikasi bisa dilakukan. Perhitungan klasifikasi untuk kalimat: Iphone camera is amazing bisa dilakukan seperti pada tabel 6 berikut ini:

Tabel 6. Perhitungan klasifikasi data

\begin{tabular}{lcc}
\hline Item Perhitungan & $\mathrm{C}=$ positif & $\mathrm{C}=$ negatif \\
\hline Prior probability $P(C)$ & 0.5 & 0.5 \\
$\mathrm{P}(\mathrm{x}=$ iphone $\mid \mathrm{C})$ & 0.1053 & 0.1053 \\
$\mathrm{P}(\mathrm{x}=$ camera $\mid \mathrm{C})$ & 0.0526 & 0.0789 \\
$\mathrm{P}(\mathrm{x}=\mathrm{is} \mid \mathrm{C})$ & 0.1316 & 0.1053 \\
$\mathrm{P}(\mathrm{x}=$ amazing $\mid \mathrm{C})$ & 0.1316 & 0.0263 \\
Product Probability & 0.000048 & 0.000012 \\
\hline
\end{tabular}

Dengan hasil perhitungan di Tabel 6 dan persamaan (2) maka keputusan klasifikasi nä̈ve bayes atas kalimat tersebut adalah positif. Keputusan ini diambil karena nilai total product probability untuk kelas positif lebih tinggi dibandingkan dengan kelas negatif. 


\subsubsection{Rancangan Sistem}

Kerangka sistem informasi yang diajukan seperti pada Gambar 5 dan Deskripsi detail alur sistem pada Gambar 6 berikut ini:

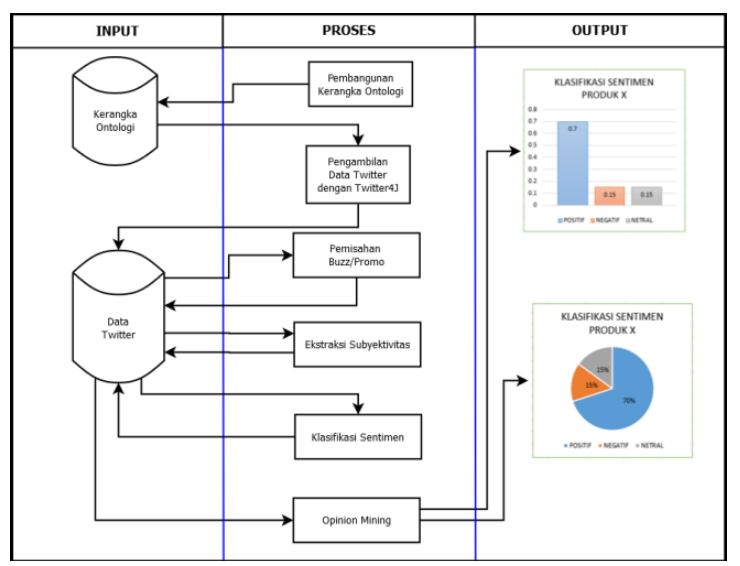

Gambar 5. Kerangka sistem informasi klasifikasi sentimen berbasis ontology

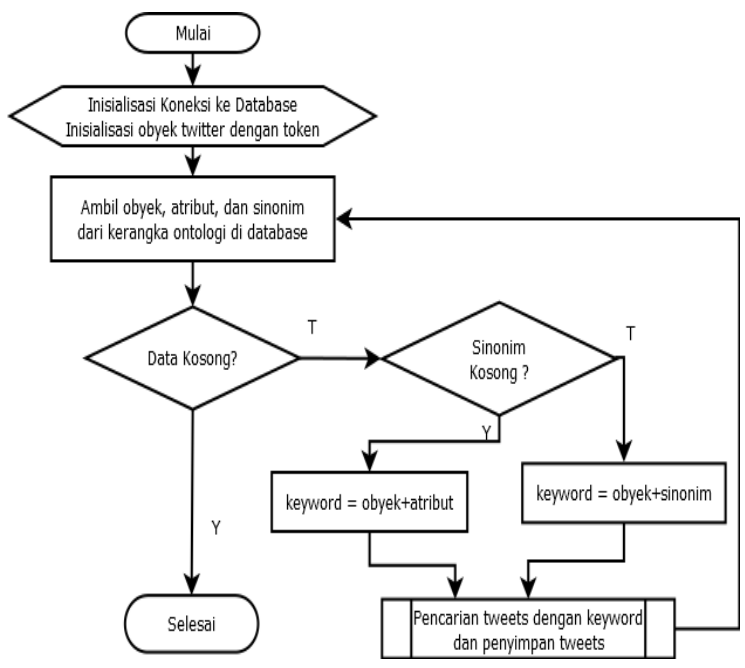

Gambar 6. Deskripsi alur sistem

\section{A. Pembangunan Kerangka Ontologi}

Kerangka ontologi dengan domain smartphone yang telah ditentukan sebelumnya dalam gambar 4 dibangun dengan menggunakan database MySQL. Setiap Obyek disimpan dalam tabel corpus_object begitu juga dengan atribut untuk setiap obyek disimpan dalam tabel corpus_attribute. Struktur yang digunakan seperti pada Tabel 7 dan Tabel 8.

Tabel 7. Struktur tabel corpus_object

\begin{tabular}{lll}
\hline Kolom & \multicolumn{1}{c}{ Tipe } & \multicolumn{1}{c}{ Keterangan } \\
\hline Id & TINYINT & Id setiap obyek \\
object & VARCHAR(50) & Nama obyek, unik \\
\hline
\end{tabular}

Tabel 8. Struktur tabel corpus_attribute

\begin{tabular}{ccc}
\hline Kolom & Tipe & Keterangan \\
\hline id & TINYINT & Id setiap atribut \\
attribute & VARCHAR(50) & Nama atribut, unik \\
\hline
\end{tabular}

Setiap atribut ada kemungkinan mempunyai sinonim, untuk itu perlu ditambahkan daftar sinonim yang diperlukan untuk memperluas atribut ini. Struktur tabel sinonim dibuat seperti pada Tabel 9.

Tabel 9. Struktur tabel corpus_attribute_synonym

\begin{tabular}{ccc}
\hline $\begin{array}{c}\text { Nama } \\
\text { Kolom }\end{array}$ & Tipe & Keterangan \\
\hline id & TINYINT & Id setiap sinonim \\
at_id & TINYINT & Id attribut \\
attribute & VARCHAR(50) & Nama atribut, unik \\
\hline
\end{tabular}

Keyword yang digunakan untuk pencarian di twitter dengan menggunakan pustaka Twitter4J dibentuk dengan menggabungkan obyek dan atributnya atau obyek dengan sinonim dari atribut.

Antar muka pembangunan kerangka ontologi ini dibuat dengan menggunakan bahasa pemrograman java dengan perangkat pengembang netbeans 8.0. Gambar 7 berikut adalah tampilan antar muka pembangunan kerangka ontologi tersebut:

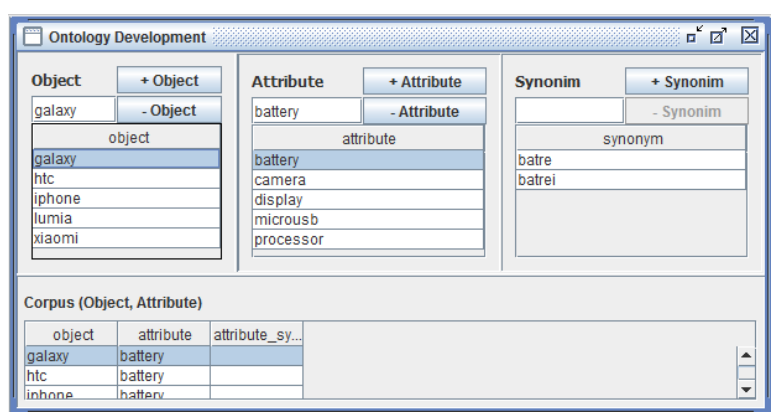

Gambar 7. Tampilan antar muka pembangunan kerangka ontologi

\section{B. Pengambilan Data Twitter dengan Twitter4J}

Pengambilan tweets di Twitter dengan menggunakan pustaka Twitter4J dilakukan dengan menggunakan kerangka ontologi yang telah dibentuk pada langkah sebelumnya. Sesuai dengan ketentuan Twitter, setiap aplikasi yang akan mengambil data tweets harus mengikuti aturan yang sudah ditentukan. Diantara aturan tersebut antara lain :

a. Setiap aplikasi yang akan menggunakan Twitter API harus mendapatkan token otentikasi OAuth terlebih dahulu (https://dev.twitter.com/oauth/overview).

b. Setiap penggunaan fungsi pencarian sesuai dengan standar API terbaru versi 1.1, dibatasi dengan maksimal 180 kali pencarian setiap 15 menit

(https://dev.twitter.com/rest/reference/get/search/ tweets).

c. Sisa fasilitas fungsi pencarian yang belum digunakan bisa dicek dengan menggunakan api application/rate_limit_status

(https://dev.twitter.com/rest/reference/get/applica tion/rate_limit_status). 
Dengan menggunakan pustaka Twitter4j proses pengambilan data tweets bisa lebih mudah, dengan memasukkan data-data yang diperlukan seperti token akses OAuth, keyword pencarian, beserta data batasan pencarian seperti mulai limit id, limit tanggal, dan jumlah maksimal tweets per-pencarian

Berdasarkan kerangka ontologi yang telah disusun, untuk setiap obyek, atribut dan sinonimnya, jika ada sinonim maka diproses terlebih dahulu proses downloadnya dengan kata kunci pencarian “obyek sinonim". Sedangkan jika sinonimnya kosong maka kata kunci pencarian yang digunakan dalam bentuk "obyek atribut". Untuk setiap tweets yang berhasil di download dilakukan proses pembersihan terhadap tweets yang meliputi:

a. Menghapus karakter non-latin

b. Menghapus url yang ada

c. Menghapus tanda hashtag "\#” tanpa menghapus konten yang ada dalam hashtag tersebut.

d. Untuk tweets yang merupakan retweets asli tidak disimpan dengan pertimbangan tidak ada tambahan informasi kecuali berupa dukungan.

e. Tweets yang merupakan hasil pencarian lebih dari satu kunci pencarian (kombinasi obyek dan atribut yang berbeda) dikesampingkan dari pemrosesan lanjutan.

Diagram alir untuk proses pencarian tweets dan penyimpanannya bisa digambarkan dalam Gambar 8 berikut ini:

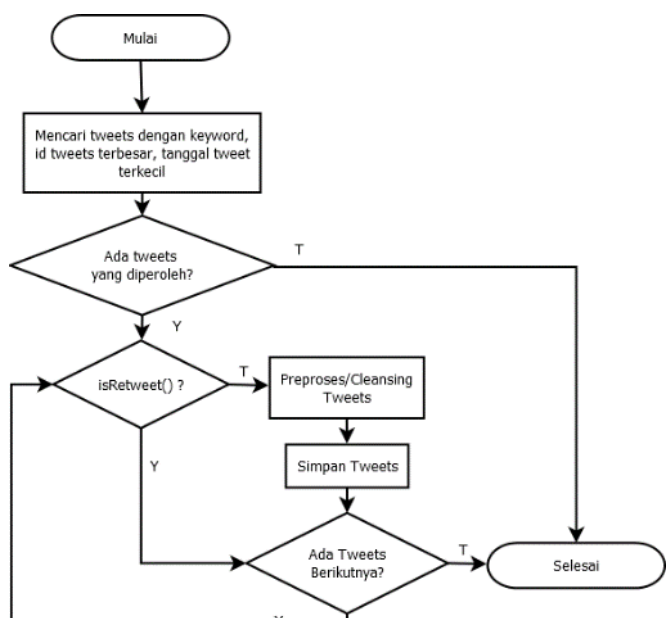

Gambar 8. Diagram alir untuk pencarian dan penyimpanan tweets

Tampilan antar muka blok sistem untuk pengambilan data tweets dengan kemungkinan mengambil per-obyek per-atribut atau semua dibuat dengan menggunakan bahasa pemrograman java dan memanfaatkan teknik threading sehingga pada saat proses komunikasi dengan situs twitter.com bisa berjalan di background tidak satu proses dengan gui dari aplikasi. Tampilan antar muka tersebut seperti pada Gambar 9 berikut ini:

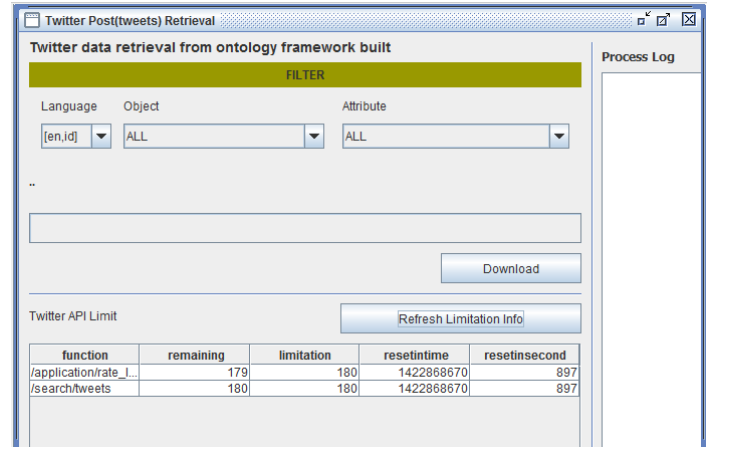

Gambar 9. Tampilan antar muka pengambilan data twitter

Tweets yang sudah terkoleksi akan diklasifikasi dengan tujuan akhir untuk mendapatkan sentimen atas produk smartphone sesuai dengan atribut yang ada. Proses klasifikasi dilakukan melewati tiga lapisan secara berurutan. Keluaran klasifikasi lapisan pertama akan menjadi masukan bagi lapisan klasifikasi beriktunya. Keluaran lapisan klasifikasi terakhir akan menjadi masukan untuk pelaporan rekapitulasi sentimen (Opinion Mining).

\section{Pemisahan Buzz/Promo}

Lapisan pertama klasifikasi ini digunakan untuk memisahkan tweets yang berupa buzz periklanan dari data tweets yang ada. Tweetsbuzz / iklan biasanya dilakukan oleh pengguna yang biasa disebut buzzer dengan ikut menyebarkan iklan dari perusahaan periklanan dan mendapatkan imbalan finansial. Biasanya tweets buzz seperti ini dilakukan berulangulang dan mengandung kata-kata seperti "Deals", "Best Deals", "Today Deals" dan beberapa kata lain.

Untuk menangani pemisahan tweetsbuzz dan nonbuzz digunakan algoritma klasifikasi naïve bayes. Algoritma klasifikasi Nä̈ve Bayes dilatih dengan sejumlah tweets yang dianotasi secara manual sebagai tweets buzz dan yang bukan tweets buzz. Hasil pelatihan merupakan model klasifikasi yang digunakan untuk melakukan pemisahan data tweets yang ada Keluaran dari lapisan klasifikasi ini adalah tweets yang sudah dipisahkan antara tweets buzz dan tweets non-buzz. Tweets non-buzz akan diteruskan ke lapisan berikutnya sebagai masukan. Contoh klasifikasi yang dilakukan di layer ini seperti yang terlihat pada gambar 10 berikut ini:

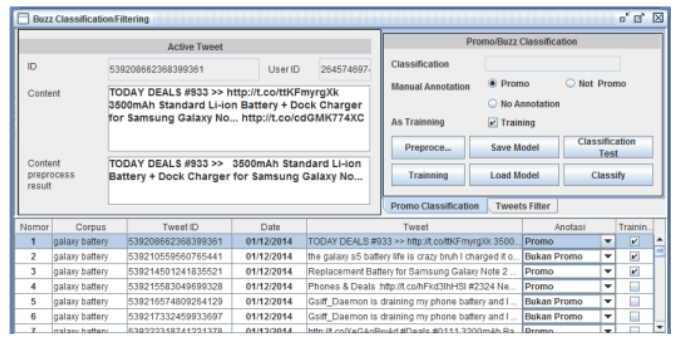

Gambar 10. Lapisan klasifikasi Tweets Buzz dan Non-Buzz 


\section{Ekstraksi Subyektivitas}

Lapisan klasifikasi ini bertujuan untuk memisahkan tweets yang subyektif dan tweets yang obyektif dari masukan tweets lapisan sebelumnya. Tweets subyektif adalah tweets yang berisi opini, persepsi, atau pendapat pengirim tweets. Sedangkan tweets obyektif diluar itu, bisa berupa berita.

Pemisahan tweets ini dilakukan dengan menggunakan algoritma klasifikasi nä̈ve bayes yang dilatih dengan data tweets yang sudah dilabeli secara manual sebagai tweets subyektif dan tweets obyektif.

Keluaran lapisan ini adalah tweets yang sudah dikelompokkan sebagai tweets subyektif dan tweets obyektif. Tweets subyektif akan diteruskan sebagai masukan untuk lapisan klasifikasi. Contoh tampilan antar muka lapisan klasifikasi ini seperti pada gambar 11 berikut ini:

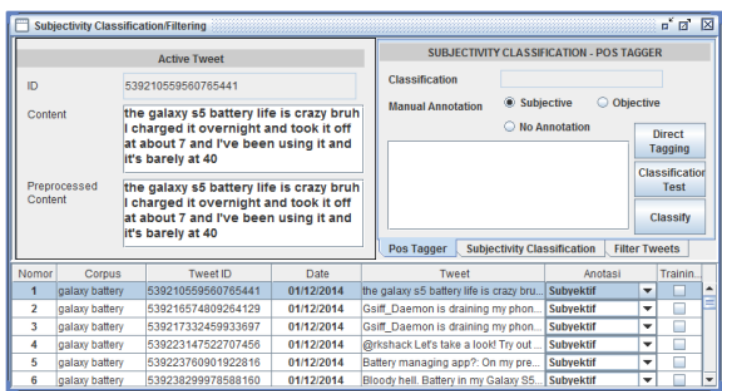

Gambar 11. Lapisan klasifikasi subyektivitas

\section{E. Klasifikasi Sentimen}

Klasifikasi sentimen merupakan lapisan terakhir untuk klasifikasi tweets untuk mendapatkan persepsi umum tentang produk yang dituju. Masukan dari lapisan ini berasal dari lapisan sebelumnya yaitu tweets yang dikategorikan sebagai tweets subyektif.

Untuk keperluan analisis tweets subyektif yang didapat dianotasi manual sebagai tweets yang positif, negatif, dan netral. Dari data tersebut sebagian digunakan sebagai data pelatihan dan selebihnya digunakan sebagai data uji.

Model yang dibentuk untuk mengklasifikasikan tweets ini menggunakan algoritma klasifikasi naïve bayes dengan multi klas sebagai keluaran. Kelas yang dituju adalah positif, negatif, dan netral. Hasil klasifikasi ini disimpan di database sebagai bahan untuk pelaporan dan analisis penambangan data / Opinion Mining. Contoh tampilan antar muka yang dirancang untuk klasifikasi sentimen ini seperti pada gambar 12 seperti di bawah ini:

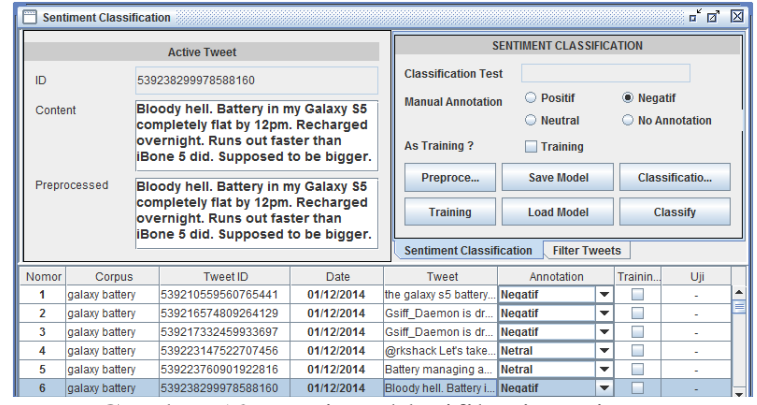

Gambar 12. Lapisan klasifikasi sentimen

\section{F. Opinion Mining}

Lapisan OM (Opinion Mining) ini merupakan lapisan akhir dari sistem ini. Tujuan lapisan ini adalah memanfaatkan hasil proses sebelumnya untuk ditampilkan dalam format grafikal ataupun tabular supaya bisa lebih dimengerti.

Contoh tampilan laporan dalam lapisan ini seperti ditunjukkan pada Gambar 13 dan 14 berikut ini:

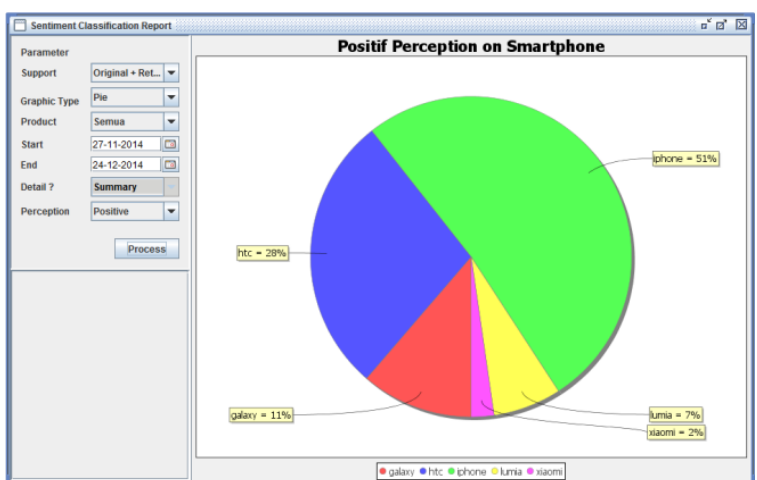

Gambar 13. Laporan sentimen dalam bentuk grafik pie

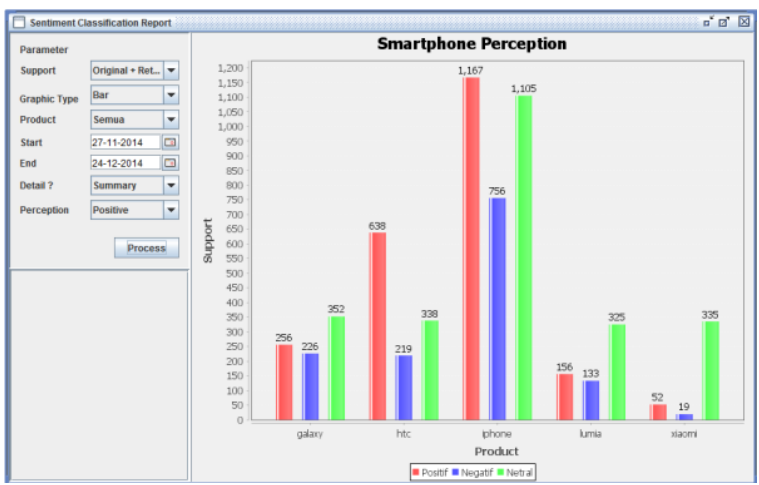

Gambar 14. Laporan sentimen dalam bentuk grafik batang

\subsubsection{Pelatihan dan Pengujian Sistem}

Tiga buah lapisan klasifikasi yang dibuat, dilatih dengan menggunakan data tweets yang diperoleh dari hasil pengambilan data dari situs twitter. Untuk keperluan pelatihan ini, data tweets dianotasi secara manual. Data tweets yang digunakan untuk pelatihan ini seperti yang disajikan dalam Tabel 10, 11, dan 12 berikut ini: 
Tabel 10. Anotasi manual klasifikasi promo/n-promo

\begin{tabular}{cc}
\hline Tipe Anotasi & Jumlah Data \\
\hline Promo & 4.350 \\
N-Promo & 4.350 \\
\hline
\end{tabular}

Tabel 11.Anotasi manual subyektivitas

\begin{tabular}{cc}
\hline Tipe Anotasi & Jumlah Data \\
\hline Subyektif & 3.068 \\
Obyektif & 1.282 \\
\hline
\end{tabular}

Tabel 12.Anotasi manual sentimen

\begin{tabular}{cc}
\hline Tipe Anotasi & Jumlah Data \\
\hline Positif & 1.169 \\
Negatif & 953 \\
Netral & 946 \\
\hline
\end{tabular}

Setiap lapisan dilatih dan diuji dengan data seperti yang ada di Tabel 10, 11, dan 12 dengan komposisi perbandingan untuk data latih dan data uji 25\%:75\%, 50\%:50\%, dan 75\%:25\%. Untuk masingmasing komposisi dilakukan pengukuran sebanyak 10 kali dengan pengambilan data acak untuk masingmasing data latih dan data uji.

\section{Hasil dan Pembahasan}

\subsection{Penggunaan Kerangka Ontologi}

Dari 14.437 tweets yang diperoleh dari twitter diteliti dengan menggunakan sejumlah perintah query untuk mengetahui jumlah tweets yang diluar domain smartphone. Dari hasil pengecekan, ditemukan ada 13 tweets yang diluar domain smartphone. Tweets tersebut mengandung keyword yang benar (galaxy camera, galaxy screen) tetapi mengarah ke domain film (The Guardian of The Galaxy).

Kejadian ini memungkinkan sekali terjadi karena tweets adalah tulisan bebas dari pengguna. Untuk meminimalkan hasil pencarian ini bisa dengan menggunakan keyword yang lebih spesifik.

\subsection{Pengujian lapisan klasifikasi}

Tiga buah lapisan klasifikasi di uji dengan metode seperti yang dijelaskan di bagian 3.3.6. Hasil rata-rata pengujian untuk masing-masing lapisan seperti yang disajikan dalam tabel 13, 14, dan 15 di bawah ini:
Tabel 13. Rata-rata pengujian klasifikasi Promo

\begin{tabular}{ccccc}
\hline Kelas & Precision & Recall & $\begin{array}{c}\text { F- } \\
\text { Measure }\end{array}$ & Accuracy \\
\hline 25_ori & 0.9625 & 0.9557 & 0.9590 & 0.9591 \\
25_buzz & 0.9560 & 0.9626 & 0.9593 & \\
50_ori & 0.9693 & 0.9642 & 0.9667 & 0.9667 \\
50_buzz & 0.9644 & 0.9692 & 0.9668 & \\
75_ori & 0.9769 & 0.9688 & 0.9728 & 0.9728 \\
75_buzz & 0.9690 & 0.9769 & 0.9729 & \\
\hline
\end{tabular}

Berdasarkan hasil pengujian yang disajikan di tabel 13, model yang dikembangkan di subsistem ini memiliki tingkat akurasi yang cukup tinggi. Tingkat akurasi yang dihasilkan dengan data pelatihan $25 \%$ menghasilkan nilai 0.9591 yang berarti sangat mendekati nilai 1 . Begitu juga untuk data pelatihan $50 \%$ dan $75 \%$ dengan tingkat akurasi 0.9667 dan 0.9728, masing-masing memiliki tingkat akurasi yang cenderung naik jika data pelatihannya ditambah.

Untuk nilai precision dan recall memiliki kecenderungan yang sama dengan menghitung harmonic mean (F-Measure) dari kedua variabel tersebut. Untuk masing-masing kelas setiap komposisi uji $(25 \%, 50 \%, 75 \%)$, nilai precision untuk kelas tweetsori memiliki kecenderungan lebih tinggi dari kelas tweets buzz walaupun dengan selisih yang kecil (berbeda di digit ketiga desimal).

Dengan nilai-nilai yang dihasilkan seperti yang tersaji dalam tabel 13, model untuk subsistem klasifikasi promo dan bukan promo memberikan tingkat keakuratan yang tinggi.

Tabel 14. Rata-rata pengujian lapisan subyektivitas

\begin{tabular}{ccccl}
\hline Kelas & Precision & Recall & $\begin{array}{c}\text { F- } \\
\text { Measure }\end{array}$ & Accuracy \\
\hline 25_subj & 0.9312 & 0.8943 & 0.9123 & 0.8788 \\
25_obj & 0.7693 & 0.8418 & 0.8037 & \\
50_subj & 0.9343 & 0.9203 & 0.9273 & 0.8982 \\
50_obj & 0.8161 & 0.8451 & 0.8303 & \\
75_subj & 0.9385 & 0.9370 & 0.9377 & 0.9122 \\
75_obj & 0.8503 & 0.8530 & 0.8514 & \\
\hline
\end{tabular}

Berdasarkan hasil uji yang tertera di tabel 14 di atas, model yang dikembangkan untuk subsistem ini memiliki tingkat akurasi yang tinggi seperti yang ada di kolom accuracy. Untuk kolom precision dan recall juga mendukung tingkat akurasi ini. Untuk masing-masing kelompok komposisi, kelas subyektif memiliki nilai precision yang lebih tinggi dibandingkan dengan kelas obyektif. Begitu juga untuk nilai harmonic mean (F-Measure) dari masingmasing kelas di setiap komposisi ini.

Tingkat akurasi yang ada di subsistem ini memiliki nilai lebih rendah dibandingkan dengan tingkat akurasi yang ada di subsistem sebelumnya. Penyebabnya adalah tingkat kerumitan untuk memisahkan antara tweets yang subyektif dan tweets 
yang obyektif lebih tinggi dibandingkan pemisahan pada subsistem sebelumnya.

Tabel 15. Rata-rata pengujian lapisan sentimen

\begin{tabular}{ccccc}
\hline Kelas & Precision & Recall & $\begin{array}{c}\text { F- } \\
\text { Measure }\end{array}$ & Accuracy \\
\hline 25_pos & 0.8134 & 0.6854 & 0.7435 & \\
25_neg & 0.5666 & 0.8565 & 0.6815 & 0.6868 \\
25_neu & 0.7681 & 0.5175 & 0.6169 & \\
50_pos & 0.8368 & 0.7126 & 0.7695 & \\
50_neg & 0.5954 & 0.8962 & 0.7153 & 0.7197 \\
50_neu & 0.8194 & 0.5503 & 0.6577 & \\
75_pos & 0.8565 & 0.7328 & 0.7896 & \\
75_neg & 0.6142 & 0.9151 & 0.7346 & 0.7411 \\
75_neu & 0.8454 & 0.5759 & 0.6839 & \\
\hline
\end{tabular}

Berdasarkan hasil uji yang disajikan di tabel 15, tingkat akurasi model klasifikasi cukup tinggi dengan maksimal nilai 0.7411. Dari tabel tersebut model ini cukup bisa mengenali tweets dengan sentimen positif dan netral dibandingkan dengan tweets yang memiliki sentimen negatif. Hal ini dibuktikan dengan nilai precision yang lebih tinggi untuk tweets positif dan netral dibandingkan dengan tweets negatif.

Tingkat akurasi model di subsistem ini lebih rendah dibandingkan dengan dua model sebelumnya. Hal ini karena tingkat kerumitan pemisahan untuk setiap kategori lebih tinggi dibandingkan dengan dua subsistem sebelumnya dan jumlah kelas dalam model ini lebih banyak dari dua model sebelumnya. Jumlah kelas yang lebih banyak ini juga akan menambah kerumitan pemisahan di model ini.

Rata-rata pengujian dari semua lapisan klasifikasi ini disajikan dalam tabel 16 berikut ini:

Tabel 16. Rata-rata pengujian keseluruhan sistem

\begin{tabular}{cccccc}
\hline $\begin{array}{c}\text { Kompo- } \\
\text { sisi }\end{array}$ & $\begin{array}{c}\text { Sub- } \\
\text { sistem } \\
\text { Promo }\end{array}$ & $\begin{array}{c}\text { Sub- } \\
\text { sistem } \\
\text { Subyek- } \\
\text { tivitas }\end{array}$ & $\begin{array}{c}\text { Sub- } \\
\text { sistem } \\
\text { Senti- } \\
\text { men }\end{array}$ & $\begin{array}{c}\text { Rata- } \\
\text { rata }\end{array}$ & $\%$ \\
\hline $25: 75$ & 0.9591 & 0.8788 & 0.6868 & 0.8416 & $84.16 \%$ \\
$50: 50$ & 0.9667 & 0.8982 & 0.7197 & 0.8615 & $86.15 \%$ \\
$75: 25$ & 0.9728 & 0.9122 & 0.7411 & 0.8754 & $87.54 \%$ \\
\hline
\end{tabular}

\section{Kesimpulan}

Penggunaan kerangka ontologi untuk pencarian data di twitter terbukti mampu mempertajam hasilnya. Dari 14.437 tweets yang diteliti ditemukan 13 tweets yang tidak terkait dengan domain pembahasan. data ini tentu tidak terlalu signifikan dari total hasil pencarian.

Penggunaan algoritma klasifikasi nä̈ve bayes terbukti mampu untuk mengklasifikasi tweets dengan tingkat akurasi yang tinggi. Hal ini dibuktikan dengan hasil rata-rata uji di masing-masing lapisan klasifikasi yang disajikan di tabel 13, 14, dan 15 . Juga untuk rata-rata keseluruhan sistem yang disajikan di tabel 16. Hasil akurasi yang bisa dicapai berada pada kisaran $84.16 \%$ sampai dengan $87.54 \%$.

Hal-hal yang perlu diperhatikan dalam analisis ini, seperti: penggunaan kata kunci yang spesifik supaya bisa mendapatkan hasil pencari-an yang sesuai dengan domain pembahasan, anotasi manual untuk pelatihan dan pengujian sistem, danprapemrosesan data tweets (cleaning) juga ikut mempengaruhi hasil klasifikasi.

\section{Daftar Pustaka}

Abrahamsson, P., Salo, O., Ronkainen, J. dan Warsta, J., 2002. Agile software development methods: Review and analysis, VTT Publication.

Chen, L., Wang, F., Qi, L., dan Liang, F., 2014. Experiment on sentiment embedded comparison interface, Knowledge-Based Systems, 64, 44-58.

Ghiassi, M., Skinner, J., dan Zimbra, D., 2013. Twitter brand sentiment analysis: A hybrid system using n-gram analysis and dynamic artificial neural network, Expert Systems with Applications: An International Journal, 40(16), 6266-6282.

Haddi, E., Liu, X., dan Shi, Y., 2013. The role of text pre-processing in sentiment analysis, Procedia Computer Science, 17, 26-32.

He, Y., dan Zhou, D., 2011. Self-training from labeled features for sentiment analysis, Information Processing \& Management, 47 (4), 606-616.

Kontopoulos, E., Berberidis, C., Dergiades, T., dan Bassiliades, N., 2013. Ontology-based sentiment analysis of twitter posts, Expert systems with applications, 40(10), 4065-4074.

Liu, B., 2011. Web Data Mining: Exploring Hyperlinks, Contents, and Usage Data, Second Edition, Springer.

Liu, B., 2010. Sentimen Analysis and Subjectivity In: Indurkhya, N., Damerau, F. J. (Eds.), HANDBOOK OF NATURAL LANGUAGE PROCESSING, Second Edition. Boca Raton, FL, 627-666.

Maks, I., dan Vossen, P., 2012. A lexicon model for deep sentiment analysis and opinion mining applications, Decision Support Systems, 53(4), 680-688.

Manning, C.D., Raghavan, P., dan Schütze, H., 2008. Introduction to information retrieval, Cambridge: Cambridge university press.

Medhat, W., Hassan, A., dan Korashy, H., 2014. Sentiment analysis algorithms and applications: A survey,Ain Shams Engineering Journal,5, 10931113

Mukherjee, S., dan Sharma, N., 2012. Intrusion detection using naive Bayes classifier with feature reduction, Procedia Technology, 4, 119-128.

Peñalver-Martinez, I., Garcia-Sanchez, F., ValenciaGarcia, R., Rodríguez-García, M. Á., Moreno, V., 
Fraga, A., dan Sánchez-Cervantes, J. L., 2014. Feature-based opinion mining through ontologies, Expert Systems with Applications, 41(13), 59956008.

Taboada, M., Brooke, J., Tofiloski, M., Voll, K., dan Stede, M., 2011. Lexicon-based methods for sentiment analysis, Computational linguistics, 37(2), 267-307.

Toutanova, K., Klein, D., Manning, C. D., dan Singer, Y., 2003. Feature-rich part-of-speech tagging with a cyclic dependency network, Proceedings of the 2003 Conference of the North American Chapter of the Association for Computational Linguistics on Human Language Technology, vol 1, 173-180.

Unnamalai, K., 2012. Sentiment analysis of products using web, Procedia Engineering, 38, 2257-2262.
Wicaksono, A. F., dan Purwarianti, A., 2010. HMM based part-of-speech tagger for Bahasa Indonesia, In Fourth International MALINDO Workshop, Jakarta.

Zhang, H., 2004. The optimality of naive Bayes,Proceedings of the Seventeenth Florida Articial Intelligence Research Society Conference, Florida,562-567.

Zhang, L., Ghosh, R., Dekhil, M., Hsu, M., dan Liu, B., 2011. Combining lexicon-based and learningbased methods for Twitter sentiment analysis, HP Laboratories, Technical Report HPL-2011, 89.

Zhou, S., Chen, Q., dan Wang, X., 2014. Fuzzy deep belief networks for semi-supervised sentiment classification, Neurocomputing, 131, 312-322. 